Article

\title{
Online Martyrs: Virtual Tours of the Miguel Agustín Pro Museum, and the José Simeón Cañas Central American University Martyrs
}

\author{
Marisol Lopez-Menendez \\ Department of Social and Political Sciences, Universidad iberoamericana-Ciudad de México, \\ 01219 Ciudad de México, CDMX, Mexico; marisol.lopez@ibero.mx
}

Received: 24 June 2019; Accepted: 6 September 2019; Published: 10 September 2019

\begin{abstract}
This article examines two commemorative projects on 20th-century Jesuit martyrs turned into Internet tours. A comparison between the official online tour of the Father Pro Museum in Mexico City, and two unofficial tours through the Martyrs Memorial Hall at the José Simeón Cañas Central American University in San Salvador, El Salvador, suggests paradoxes regarding a museum's online representation and ways in which violence and martyrdom are represented.
\end{abstract}

Keywords: martyrdom; memory; museums; Internet

\section{Introduction}

Social networks and the impact of the Internet have been analyzed from different theoretical lenses, and a growing number of publications can confirm academia's interest in understanding a phenomenon that in only 30 years appears to have transformed cognitive, social, and information-spreading habits.

Virtual museums date back to the 1990s; some authors (Coddy 1997; Jones-Garmil 1997) note that they have been criticized both as museums and educational arenas, and as spaces for memory and commemoration. Virtual museums bring together discussion techniques about the past and new visual technologies, thereby recovering in a way the origins of the modern museum (Bennett 1995).

Being virtual in this sense represents the possibility of being in a certain place that for whatever reason is inaccessible physically, making the visit possible and thus building an alternative way of taking in the past that might otherwise seem disassociated from the geographic location.

The idea for this article came from a comparative effort between two commemoration projects on 20th-century Jesuit martyrs who have been represented in museums. This type of representation is particularly interesting, since a museum is more characteristic of modern, (secular) nation-states than of the Catholic Church. This point provides us with some guidelines to interpret the subtle and often troublesome gray areas where religion and politics insist on overlapping, despite its separation in modern conceptions and mindsets.

A museum, conceived originally as a place for the selective representation of episodes related to the reinforcement of the nation-state and its commemorations, has become a "delocalized" event (Deloche 2002). There has also been a worldwide tendency to preserve memory by creating museums that commemorate violent events and attempting to reproduce for the visitor the experience of genocide—such as the Yad Vashem or the Auschwitz-Birkenau Museum—or of systematic, ongoing violent practices, such as the recently inaugurated National Museum of African American History and Culture. As Benedict Anderson notes in his classic Imagined Communities, the educational industry of the museum has been consistently linked to the dynamics of remembering/forgetting violent acts (Anderson 1991). 
In this sense, the virtual museums we shall study here have significance. Even though both make the virtual experience possible, their very existence is centered on the place as a symbolic arena where the events occurred, where the protagonists lived, and, in the case of the José Simeón Cañas Central American University (UCA), the very place they died. The goal of this article is to analyze virtual projects created in physical museums - the Monsignor Romero Center and Martyrs Museum at José Simeón Cañas Central American University in San Salvador, and the Father Pro Museum in Mexico City.

Both cases represent projects protected and embraced by the Society of Jesus. Both cases refer to violent acts, and both have been built on sites of memory, according to Nora's (2001) classic definition. According to this French historian, the notion refers to places where memory is anchored, crystallized, and expressed collectively, and can be resignified to incorporate new ways of thinking about the past.

The site museum transformed into a virtual tour is unique in that it preserves its nature as a "place of memory", while at the same time its delocalization allows it to respond to different narratives; delocalization allows the museum to be read from different historical and cultural viewpoints, so the virtual tour opens the possibility of creating different types of memory.

The virtual museum is more than a tour, more than an experience to be had, more than a specific place. It is something paradoxical in museums whose main meaning is linked to a place-such as in the case of the museums analyzed here.

These two museums are places where the memory of violent acts is preserved and emotions are evoked in the hopes of moving the spectator and pushing him or her to take a stand against state policies. Both museums are also historical landmarks and places where grief and homage are associated with history to build narratives that make sense of the protagonists' deaths, and are positioned explicitly as stories of martyrdom.

This text compares the virtual tours of the museums dedicated to the Mexican Jesuit priest Miguel Agustín Pro in Mexico City, and the martyrs of the José Simeón Cañas Central American University in San Salvador, identifying similarities and differences between the two Jesuit projects and the ways in which virtual religious tourism is presented according to the particular politics of each of the two sites. It is important to note that the virtual tour of the Father Pro Museum is an institutional outreach related to an institutional effort and a cause for his canonization, sponsored by the Society of Jesus in Mexico, while the virtual tours of the UCA museum are not linked to the UCA institution or to the Jesuit order. One of them is the pet project of the Methodist pastor Ochoa (2011), who acts as the narrator and guide, while the other was created by members of the Inter American Press Association (IAPA) during a museum visit. In the second tour, the chronicler interviews several museum representatives who offer complementary information and reference framework that define the images by linking them to martyr narratives that came out of the Salvadorian civil war.

That the tour of the Father Pro Museum has no narrator marks a significant difference; since it is a mute tour, it prompts the Internet user to turn to other sources for narrative guidelines, especially information available on the canonization movement's website and Facebook page.

Here, I compare the ways in which the use of images and narratives of martyrs adapts to local conditions and varying audiences while at the same time offering the opportunity for contact with historically relevant places of devotion. Although the original idea for this article centered on virtual "museums", I have decided to turn to the notion of virtual tours; anchored in a fleeting, repeatable experience, the tour is not equivalent to a museum, but rather to the experience of having access to one as an observer from afar, whose characteristics and agenda are not easily discernible. A virtual tour qualifies, highlights, ignores, and separates objects, processes, and expressions incorporated in artifacts, thus building a metanarrative of the curatorial experience itself. Virtual tours make use of relics and other artifacts, creating a specific narrative anchored in the antique Church traditions studied by Brown (1981); Geary (1990), and Bynum (2011). Thus, relics remain as a relevant mnemonic device in which materiality expresses itself, embodying ideas of pain, suffering, and redemption. The importance of relic-showing in virtual tours remains a topic to investigate further. 
The study of the two virtual tours is complemented with Ignacio Ellacuría and Miguel Pro's official Facebook pages, considering the different audiences and expectations these pages represent.

Here, a word about the general outlook of those supporting the projects is in order. Miguel Pro remains a somehow controversial character. To many, he was responsible for plotting against President Elect Alvaro Obregon's life in 1927 and masterminding an attack against the politician. To others, Pro was a martyr to Catholicism, because his execution was ordered not because of what he did, but because of his firm belief in the Catholic Church's teachings and prerogatives. His death also stands out for demands of religious freedom. Yet to others, he died as a victim of injustice: the absence of due process leading to his execution makes him an early example of human rights abuses in Mexico. As we can see, Miguel Pro's story has competing narratives supported by very different groups within the Catholic milieu both in Mexico and globally.

The UCA martyrs are different. Inspired by the Second Vatican and Medellin, three of the martyred Jesuits were important thinkers of the Theology of Liberation movement. Their philosophical and theological perspectives were aligned with progressive Catholicism, and those who promoted their memory are, too.

The text is divided into four sections. The first one analyzes the specific characteristics of the virtual museum, about which there is a large body of literature, although it is not yet analytically relevant. Sections two and three cover the virtual tour of the Martyrs Memorial Hall at the Central American University in San Salvador, and the virtual tour of the Father Pro museum, respectively. The last section summarizes and discusses aspects of the representation of violence in an attempt to find similarities between the museums' approaches and how the virtual tours supported by the websites retrieve them. This final section underscores the importance of the debasement of the martyrs' bodies in the virtual tours and in the actual museums discussed.

The images were generally chosen according to those used in the virtual tours. Although I have visited both museums, I have chosen to show the readers the images available as part of the virtual tours.

\section{Virtual Spaces}

A virtual museum can be understood as the result of the erosion of a "sense of place", which, according to the historian Walsh (1992) has characteristics of post-industrial, post-modern societies. As Bennett (1995) has also suggested, museums came about as a disciplinary complement of the prison in the Foucauldian sense, because they are geared toward the transformation of working-class ways, and they impose new types of managing the body: self-restraint and respect for an object being shown contribute to create a public space different from a tavern or town square. In the first museums, eating, yelling, and touching were not allowed, so they offered a culturally differentiated area of "supervised conformity" where new types of behavior could be internalized and turned into self-regulated types of behavior. Therefore, the museum is a place for teaching an implied "civilizing" process-to use Norbert Elias" terms. The "appropriate" responses to stimuli in a museum are similar to those required when visiting a religious temple; people's voices must be deep and low, although silence is preferred. Contemplating works of art or artifacts of memory is measured by information contained on museum cards and texts that frame and make sense of what a visitor may perceive. People must not make abrupt moves or have any contact other than visual with the works shown.

It is true that museums built to commemorate martyrs are secular teaching tools, fomenting historical knowledge of a specific period and offering narratives that politically situate the deaths of the protagonists. At the same time, they are sacred repositories where objects that have been in contact with the martyrs' bodies are protected. Unlike objects in secular museums, the relics are traditionally touched by the faithful, which places a martyr museum in an interesting dilemma: Should the objects be taken care of so they can be preserved, or should the faithful be able to touch them?

This dilemma is particularly interesting in the cases of the museums studied here, because both of them involve people whom the Catholic Church has recognized as martyrs, which allows for a 
public cult. ${ }^{1}$ As we can appreciate, the museums have opted for the preservation of the artifacts, as the placement of glass panels in both museums shows. They impede any bodily contact between the faithful and relics, while at the same time guaranteeing an appropriate behavior by the visitors toward the museum, yet it goes without saying that the visitors might be confused about the separation between the eminently religious and cultural nature of the martyrdom narratives and secular expectations when visiting a museum.

In this context, the virtual museum represents a significant transformation by putting aside the place and taking for granted the intentions of those who visit contemporary museums and the emotional facets that a museum-having been incorporated as a teaching tool in our psychological structure-can exploit. A virtual tour through a museum permits a phenomenon of reciprocity that has been analyzed by Deloche (2002). Here, the production of what is perceived (the artifact) and the presentation of what is perceived (the museum, the place that shows it) are bonded in the media experience that the virtual world represents.

The emergence of the virtual museum suggests an alienation; the Internet shows a perspective of the physical space that incorporates martyrial narratives from the narrator's viewpoint, from the viewpoint of whoever puts his heart into the practice of virtual museum experiences. This situation takes on unique characteristics when the very place the museum is located plays a key role in the mnemonic structure that is central to the museum itself. This is the case of the two cases that follow.

\section{Virtual Tours: Monsignor Romero Center and the Martyrs Museum at Central American University in El Salvador}

The case of the UCA martyrs shows an even stronger bond between space and memory. The six Jesuit priests assassinated in 1989, and the two laywomen who accompanied them, died in the place where the museum now stands. It became a frequent pilgrimage spot for people who visit the university grounds, as the virtual tour created by the Inter American Press Association shows.

The small museum came about originally as an effort to preserve the objects that gave testimony to the attack on the six Jesuits and to commemorate the deaths of the two women who were sleeping in the house the night of 16 November 1989. The attack took place during the confrontations between the Farabundo Martí Front (FMLN) and the Salvadorian army.

The six men murdered had college degrees, were UCA professors, and were well-known promotors of the preferential option for the poor that came out of the Vatican II and the Medellín Episcopal Conference. Their deaths took place during the so-called Final Offensive of the Farabundo Martí National Liberation Front, and were carried out by members of the Salvadorian Army's Atlácatl Battalion. $^{2}$ The UCA Jesuit priests were part of a group of civilian victims of state repression during the El Salvador civil war, which included women, children, and men who were both laic and religious. This is the narrative and curatorial emphasis of the museum and the online tour.

The UCA martyrs are known collectively, even though some people stand out, such as Segundo Montes, Ignacio Ellacuría, and Ignacio Martín Baró, whose contributions to philosophy, sociology, the defense of human rights, social psychology, and public-opinion studies in Latin America are extremely important and have been studied on several occasions (Castro and García 2013).

1 Miguel Agustín Pro S.J. was beatified in 1988, as was Archbishop Oscar Arnulfo Romero in 2015. The UCA Martyrs Museum contains objects from several people who are considered martyrs to justice, although they have not been officially recognized by the Catholic hierarchy as martyrs to faith. Some of Romero's belongings are in the museum. The Salvadoran Ministry of Tourism counts it among the places one can visit. It keeps a short video encouraging visitors to go there to "learn about El Salvador's recent history and the characters that played a major role in those turmoil times" (El Salvador-Ministerio de Turismo) at www.mitur.gob.sv/en/travel/centro-monsenor retrieved 7/24/2019.

2 At that time, the priests Ignacio Ellacuría, Ignacio Martín Baró, Amando López, Segundo Montes, Joaquín López y López, and Juan Ramón Moreno lost their lives. Elba and Celina Ramos, a mother and daughter, were also killed. Elba worked in the home of the Jesuit priests. 
In any case, the laic and religious people who lost their lives in the Salvadoran civil war are grouped together under the name "martyrs from the UCA". In El Salvador, the collective notion of martyrdom can also be seen in the places and the virtual tours that the museum dedicates to the El Mozote (1981) and Río Sumpul victims (1980), among others.

Extrajudicial executions abounded during the second civil war (1980-1991). The report De la locura a la esperanza states that, of the 22,000 allegations of serious acts of violence received, $60 \%$ are for these types of crimes, and the testimonies attributed $85 \%$ of the cases to state agents, the paramilitary groups allied with them, and death squadrons (Organización de las Naciones Unidas 1993). On the other hand, the six Jesuits were not the only representatives of the Catholic Church assassinated during the conflict-for example, we can name Rutilio Grande and Monsignor Oscar Romero-although the death of the Jesuits led to such international censure that the negotiations between the FMLN and the Salvadoran government began soon after. The war left thousands dead and created the idea of Salvadorans as a martyred people, as the introduction to the report of the Truth Commission for El Salvador (Organización de las Naciones Unidas 1993, p. 41) confirms.

In this context of generalized violence, it is nothing strange that the Museum of the Martyrs, as it is known today, has underscored the collective nature of the victims, as have the available online tours.

"Hall of the Martyrs: The Tours" 3 begins with the rose garden (Figure 1), where the bodies of the Jesuit priests were found early in the morning of 16 November 1989. They had been slayed at the site. ${ }^{4}$

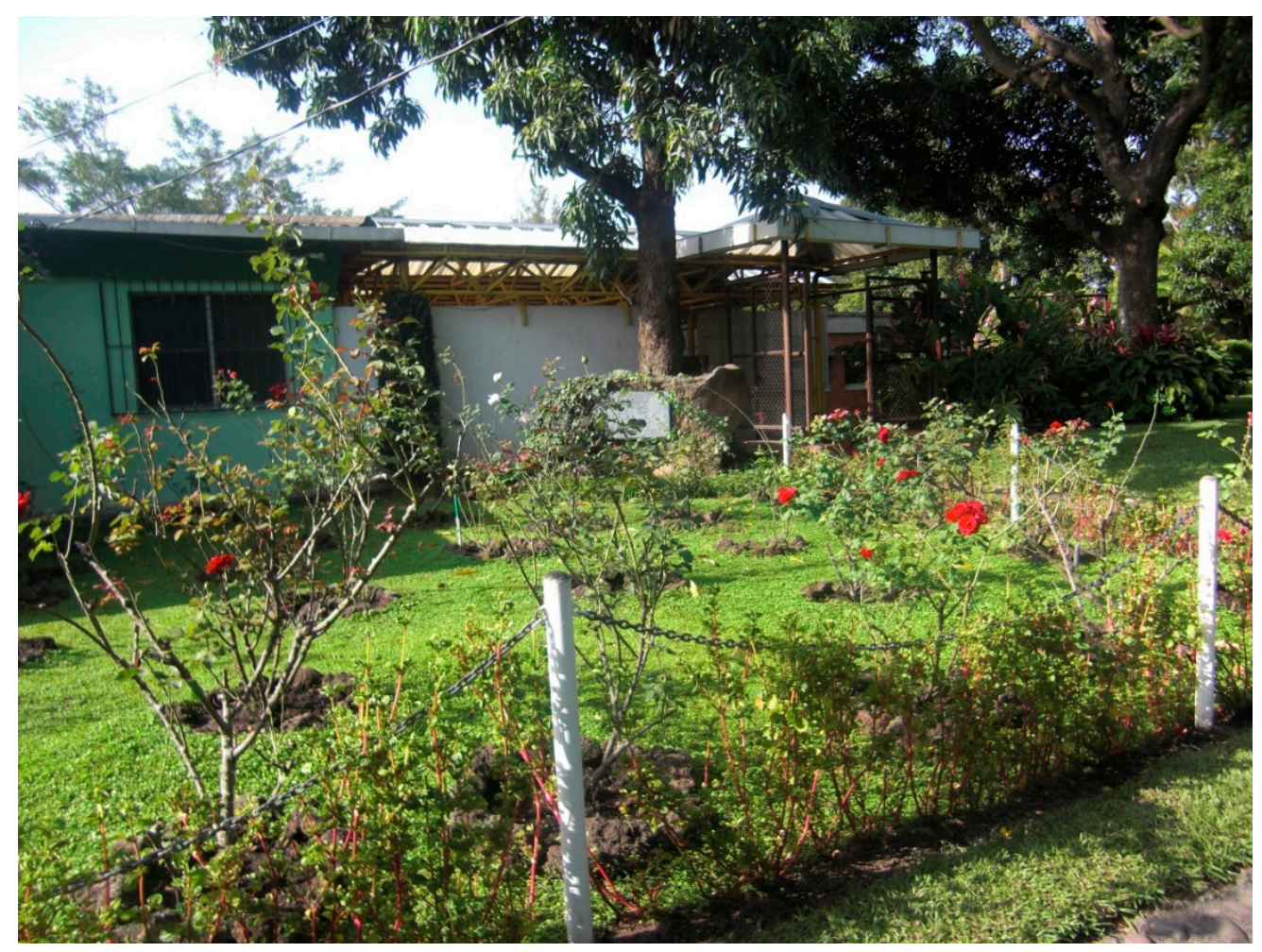

Figure 1. Garden of the Roses. The place where the UCA martyrs were executed. Photograph by Laura Teresa Sánchez, 2016.

3 As is noted above, the Methodist pastor Jorge Ochoa created the tour in 2011. https://www.youtube.com/watch? $\mathrm{v}=$ Plo1f7mZJoA Museo de los Mártires de la UCA, retrieved 13 March 2018. I contacted Ochoa on Facebook in November 2016. He authorized me to use his work-which is public anyway-although he did not want to meet with me to talk about the virtual tour of the hall of the martyrs.

4 The photograph was taken in 2016, by Laura Teresa Sánchez, whom I thank for her generosity in sharing her personal album and the virtual tour that she created of the hall of martyrs. 
The narrator talks about the massacre and reads the commemorative plaque, and then goes down the stairs and into the "Martyr Memorial Hall". After focusing the camera on a painting in which several high-ranking people seem to honor the body of a martyr, the narrator notes that we are in front of a photograph of Rutilio Grande, the Jesuit priest assassinated in March 1977, by officials of the Salvadorian government; the crime was never cleared up.

The special place that Grande occupies in the memorial is inscribed in the country's martyrial narrative and gives it meaning, since his death precipitated the "transformation" of another great Salvadorian martyr: Archbishop Oscar Arnulfo Romero. Some of Father Rutilio's personal effects are visible—a shirt, sandals, and other everyday objects.

Next, the narrator focuses on a wall with a timeline covered in photos of people assassinated during the 1978 government repression, who all had links to the church. As is noted above, the violent escalation of the civil war explains why large groups of people are represented on the virtual tour. Their number, more than their identity, accounts for the notion of martyrdom attributed to the Salvadorian people.

Monsignor Romero's cassock and cane ${ }^{5}$ are showcased, which is no coincidence, since he was the spiritual leader of the Catholic Salvadorians until 1980, the year of his death. Romero's courageous attitude, his allegations, and his resolute attitude in favor of the victims of government repression made him the first priest executed inside a Catholic temple since Thomas Beckett. Some people have seen the timid Romero's surprising and unexpected transformation after the death of his friend Rutilio Grande as a miracle in and of itself.

The narrator points out that some of the martyrs are women, somehow implying the extreme cruelty of the perpetrators by attacking defenseless people who-presumably-were unarmed. The tour shows also cartridge shells, and a sign that notes that the massacres were committed by the army, the National Guard, the Treasury Police, the National Police, the Civil Defense, and the Death Squadrons. These notes indicate that the civil war at El Salvador was one of the bloodiest conflicts in 20th-century Latin America; according to reliable sources such as De la locura a la esperanza ([1992] 1993), there were 227 massacres documented against civilians and at least at least 9967 victims, and more are being reported today.

Rutilio Grande, Oscar Romero, and the UCA priests seem to embody the great loss of human lives due to violence in the country. Their stories were crafted as those of martyrs for justice due to their stances against impunity. Thus, the virtual tours give information on 227 massacres documented in El Salvador during the civil war. The video shows the martyrs as part of a larger universe of victims, and highlights the (absurd) violence of the assassins. It is especially evident in the tour created by the Inter American Press Association in 2014, where the narrator talks about a "Bible" destroyed by bullets. The object in question is not a Bible, but a dictionary (Figure 2), and the weapon used to destroy it was a bayonet, but the error is eloquent in that it links the victims' fundamental beliefs (the Bible) to the way in which their bodies were destroyed (the bullets). ${ }^{6}$

5 Monsignor Romero was canonized by Pope Francis I on 21 October 2018, at the San Pedro Plaza. His canonization has been interpreted as an assertion of liberation theology and of the ecclesial allegations against poverty and serious human-rights violations (Anderson 2018).

6 The photograph is a screenshot of the video (Sociedad Interamericana de Prensa. V Congreso Regional 2014) Sociedad Interamericana de Prensa. V Congreso Regional. 2014. "La UCA y sus mártires", 2014. https://www.youtube.com/watch?v= J7ypd4Fkui0 (accessed on 13 March 2017). 


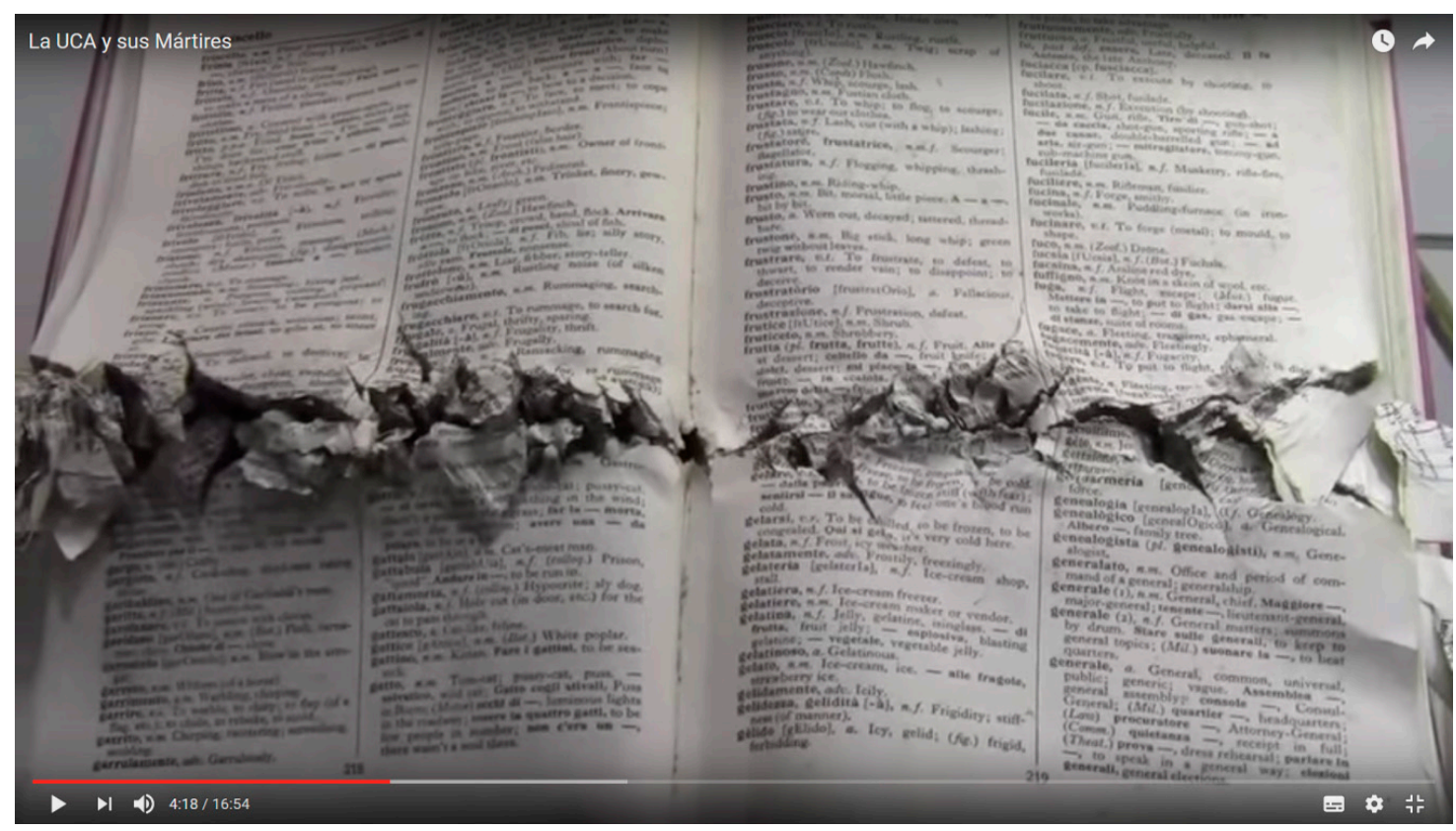

Figure 2. A book damaged during the attack to the Jesuits home. Said to be a Bible, is actually a dictionary. Screenshoot taken from Ochoa (2011).

The online experience of visiting the museum hand by hand with a sympathetic follower-Pastor Ochoa-gives the user an intense feeling of emotional distress, since his words and pitch convey his own feelings toward the site and its history. Listening to his description of the objects placed there, a new meaning arises: history is felt through the experience of a narrator whose presence at this highly charged place turns into a vicarious practice.

\section{Virtual Tours: The Father Pro Museum}

The Miguel Pro Museum is located beside the Sacred Family Church, in the centric Roma Mexico City neighborhood. The parish next to it runs the Father Pro Canonization Cause S.J., which is not fortuitous, because Miguel Pro was assigned to that parish from 1926-the year he returned to Mexico from Europe-to November 1927, when he died. Father Pro was beatified in 1988, and today, he is in the process of being canonized. Most of his biographers remember him as a promotor of Rerum Novarum social Catholicism and as an active member of the Religious Freedom Defense League, an organization led by secular Catholics who opposed the religious policies implemented by Plutarco Elías Calles' administration. Miguel Pro was the only Jesuit executed during the 1926-1929 church-state conflict. It had long roots in Mexican history, but its bloodiest episode erupted in the wake of President Calles decree prohibiting churches from celebrating mass outside church buildings; this has previously been routine. The so-called Calles Law also declared the government's right to designate the number of priests who could perform religious functions in each state of the country; moreover, it required the mandatory registration of priests before a branch of the Ministry of the Interior (Secretaría de Gobernación). (Lopez Menendez 2016, p. xix).

The Calles Law (31 July 1926) was in fact a reform of the federal penal code that forbade convents and monastic orders and expelled from Mexico all foreign priests.?

In this context, the Temple of the Sacred Family played a notable role in the strife. On 23 February 1926, its parishioners confronted the Ministry of the Interior and the Mexico City Police, who attempted to close the temple for not complying with the Calles Law. The location of the museum responds to a

7 A classic on the matter is Jean Meyer's La Cristiada (Meyer 1974). 
dense history of conflicts, and is sponsored by the canonization movement. The virtual tour (Museo de Miguel Agustín Pro SJ 2015) has some significant differences from the UCA martyr one. The first is that it is a professional production whose goal is to make the museum accessible to those unable to visit it, whether because they live in different parts of Mexico City or because of the short hours (currently, the museum is open Monday through Friday, 10:00 to 13:00). Unlike in the UCA museum, Father Pro is exalted as the epitome of victimhood of religious persecution in the country.

The Padre Pro S.J. page (the official Facebook Cause for Canonization page) was set up on 16 April 2012. On 17 March 2017, 2965 people were following it. On 24 October 2016, 2903 were following, which means that in five months, it gained 60 Internet users interested in following news about it. In January 2018, there were even more followers, 3977, and in May 2019, they were up to 5030.

The page gives information about how the canonization process is evolving and tells the faithful about the tours organized so that Father Pro's relics can visit different parishes in the Mexico City Archdiocese and other places in the country. On the page, the museum is also reported as a type of faith-related experience, where visitors from different sites-as close as Mexico City and as far as the Philippines-have paid their respects to the blessed Mexican saint and martyr.

"Keep being the best of friends," writes a faithful on the page, "Working on your Bash!!!", and "praying to you" on the night before the 88th anniversary of his death. The Facebook page highlights the priest's role as a companion of laypeople, and the figure of Pro transforms to enhance the Jesuit priesthood in general.

Furthermore, the cause for canonization profile underscores the parish's role as an animator of community life. It continuously and consistently shows images of cultural events or celebrations among laypeople, where the museum-its physical space-serves as a place of memory, as explained at the beginning of this article. By way of an example, the Facebook profile frequently uploads photographs of priests, seminarists, and nuns visiting the museum from places afar such as the Philippines or Poland. Other Catholic websites refer to the museum as a place of pilgrimage, one that might inspire conversions (Aspiring to know God 2016).

Pro's life story does not stand out on the page. His death is an excuse for a celebration, which may show that the site acts more as a way to bring together the faithful who already know about his life and death rather than as a way to spread this information about him. The site administrator often refers to the faithful as "fans" of Miguel Agustín, which has provoked some resentment among the most Orthodox, who prefer the word "faithful". It speaks of the blurred line between religious devotion and affection for a figure who is also part of the popular imagination, the culture, and the local, national, and transnational history.

There is also a website called www.padrepro.com.mx, which gives basic information about his life and death and provides virtual access to the Father Pro Museum, adjacent to the Sacred Family Parish in Mexico City, which is run by the office that promoted the pro-canonization movement. The virtual tour started in 2015 as part of the efforts to drive the canonization movement, and was opened and promoted by the Sacred Family Parish, of the Society of Jesus in Mexico (Conferencia de Provinciales Jesuitas en América Latina CPJAL 2018).

The image below (Figure 3) shows the main page of the official site for the Father Pro canonization movement. The page, run by the office for the cause, gives the reader a general overview of the site, of the place where the museum is located, and of the virtual tour-which can be accessed from the museum.

Until today (March 2019), there are |17 short videos on different YouTube channels where some Internet users have made their own virtual tours of the museum. All of them show their creators, young men, and they were uploaded in April 2016, so they may be part of a school project. They each have two or three hits. Another couple of more sophisticated videos narrate Pro's life and death, but they are not dedicated solely to the museum. However, there is one that stands out. A short rendition 
of the story of Miguel Pro's relics, provided by Father Jose Camarena S, J., former vice-postulator of the canonization cause of Father Pro before the Holy See. ${ }^{8}$

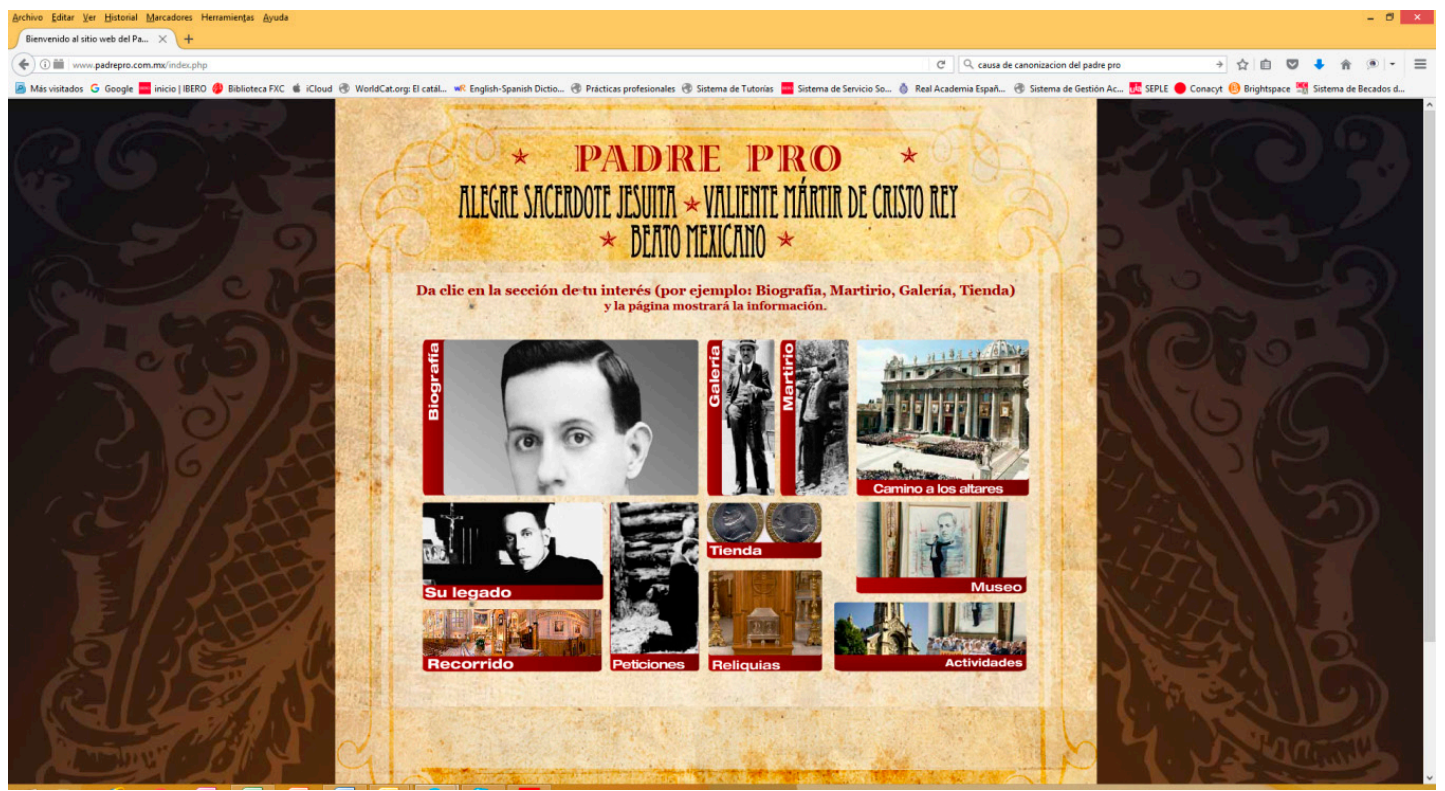

Figure 3. Main page of padre Pro’s official website. Screenshot taken on March 2019.

The virtual tour of the Pro museum shows the political scenario at the time through newspaper headlines and emphasizes the martyr's priesthood by showing sacramental objects that belonged to him. Pro is isolated from his companions and presented as a special man. The narrative that the tour runs, together with other sections of the cause for canonization webpage, is structured based on the Jesuit priesthood and his martyrdom that came about because of it.

On the virtual tour, his martyrdom does not seem to be related to others, even though his death occurred along with four other laymen. In the tour, there are explanations for his death; at least a few of them talk about the "The Cristero War" or "Cristiada", as newspaper reproductions from the time show Pro and his companions after being arrested and charged with masterminding a plot to kill President Elect Alvaro Obregon. The assassination attempt happened on 13 November. Father Pro was arrested with his two younger brothers a few days after the attack. They were charged immediately, and sentenced to capital punishment without a trial. Journalists and newspapers representatives were invited to witness the events and photographs of their deaths were first page news the morning after. ${ }^{9}$

Unlike the virtual tours about the UCA martyrs, the one about Father Pro has no sound, and the format does not allow the visitor to get close to the placards, so people must get more information about the pieces presented by reading it from the web page run by the Father Pro canonization movement. In this sense, the virtual tour of the museum tempts the curious Internet user to find out about other aspects of the canonization process that are not apparent in the museum tour.

The absence of a narration to give the virtual tour structure seems to indicate that it is not intended to take the place of a visit, but is rather an invitation to visit the actual site, thus showing the perceived limits of online tourism. The tour through the Father Pro Museum displays without

8 The current vice-postulator is Father Amado Fernández S.J., who is also living at La Sagrada familia.

9 The federal government hosted the execution after President Calles himself decided to execute Pro and the others. With Miguel Pro died Luis Segura Vilchis, Chief of the Special Command of the League for the Defense of Religious Liberty, which was a lay Catholic armed organization. Humberto Pro and Juan Tirado were both members of the league. Only Roberto, the youngest of the Pros, survived by virtue of a last-minute stay. 
telling, so it is a general overview, and there are no more narrative sequences than the curatorship of the museum exposition.

Although the virtual tour shows several objects from the exhibition, it lingers a long time on the Jesuit's clothing, what he was wearing when he was executed, his chasuble, and the stretcher where his body was placed after his execution. Similar to the UCA martyrs, the objects that touched Father Pro's blood and body are highlighted, which shows the fragile line between the religious and political spheres, between admiration for the hero and the cult to the martyr. As we will see below, the relative importance of the objects in direct contact with Pro's body can be explained by Christian reliquial traditions and the link between them and the confessional representations of violence and their impact on the body.

\section{Representations of Violence: The Debased Body in the Virtual Tours}

In his classic The Cult of the Saints, ${ }^{10}$ the historian Peter Brown noted the importance of the body and the relic as components that make up the bond between believers and martyrs, those "very special friends". The importance of the body and of contact with the body has been the object of many theological, historical, and sociological discussions. Caroline Walker Bynum ${ }^{11}$ has explored the association with medieval culture, and has explored the different ways that materiality is inscribed in the Catholic practice and in the social imagination of the time. After all, relics are bodily remains, artifacts believed to have absorbed the powers and miraculous abilities of saints and martyrs. Through relics, people remember stories and makes sense of the past, of death, and suffering. Christianity is defined as a "religion of memory" (Hoornaert 1988), because relics embody its origins, and redemptive suffering is relived through the contemplation of violence-related objects. In this sense, relics of martyrs are even more important, because they are believed to have lived up to Christ's example, while their remains retain some of the spiritual power that gave way to the "miracle" of their death.

Martyrdom comes about only when three main players come together-the martyr, his followers, and the state or the current status quo. This trio produces hagiographic narratives that are able to provide symbolic support to different, at times fluctuating, social identities.

Thus, it is possible to find cases of martyrs who have been reclaimed by groups with different or even opposing political agendas, making it necessary to take into account the different political aspects of the figure of the martyr, just as they are expressed by those who formulate death as martyrdom and those who mobilize in the martyr's name- the people who go to processions, who ask for favors, who show their affinity with the cause for which the person in question gave his life (Lopez Menendez 2015, p. 6).

Both museums are anchored in the narrative of bodily defilement as a premise and example of martyrdom, and they both place priority on different objects that had direct contact with the martyrs' bodies. This tendency can be seen in the virtual tours analyzed.

Violence is shown through clothing as a metaphor of the defiled body. In this sense, the materiality of the clothing and of the objects that had direct contact with the martyrs' bodies are shown as powerful artifacts of memory that not only refer to the spectacularity of physical pain, but also reconstitute the original sacredness (sanctity) of the relics. ${ }^{12}$ This tendency is evident in all the videos, although it is best seen in the one made by the IAPA in 2014; the shirt worn by Ignacio Martín Baró at the moment of his death and other pieces of clothing partially destroyed by the bullets are shown in detail. The close-up of the ruined clothing allows the virtual observer to get close to the drama of death and to share in the affront to the bodies as sacred objects.

10 (Brown 1981) Brown, Peter. 1981. The Cult of the Saints. Chicago: University of Chicago Press.

11 Bynum (2011) Bynum, Caroline Walker. 2011. Christian Materiality. An Essay on Religion in Late Medieval Europe. New York: Zone Books.

12 A good book on the topic is Christian Materiality, by Bynum (2011), which, even though it is a study of the High Middle Ages, shines light on the relationship between Catholicism and the materiality of objects that the faithful consider as sacred. 
Both the Museum of the Martyrs and the Pro Museum have opted to represent violence as anchored in the idea of bodily debasement; the deceased Jesuits' clothing ripped apart by bullets and the outfit Pro was wearing when he was executed are key pieces in the virtual tours. In the UCA, the voice of the narrator, the Methodist pastor Jorge Ochoa, trembles and seems about to break down in sobs when contemplating the glass behind which the victims' clothing is displayed. In the Miguel Pro Museum tour, the web page where the virtual tour is located notes that the clothing the Jesuit priest was wearing at the time of his death is one of its most important relics (Figure 4). ${ }^{13}$

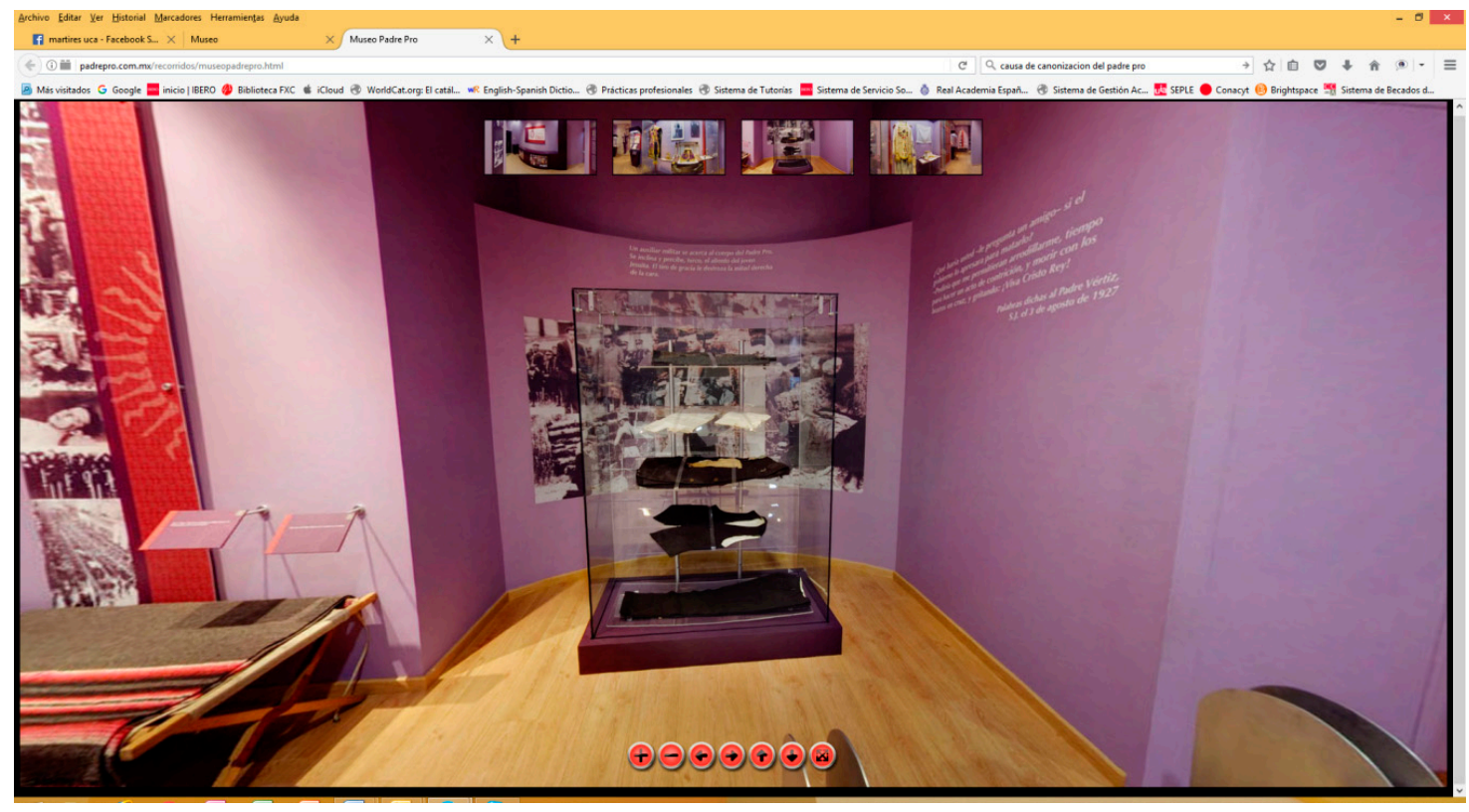

Figure 4. Clothing belonging to Father Pro. Virtual tour.

Relics also have a long story within Christianity that has been studied from several disciplines. Their importance to early Christianity and to Catholicism has been boldly highlighted. Authors such as Brown (1981); Bynum (2011); Geary (1990), and Rothkrug (2006) have shown the important role they had in medieval society, culture, and economics. The long secularization process that culminated in modern nation-states recovered the relic and incorporated it into the museum; objects belonging to national heroes are still displayed as if their original owners had instilled in them part of the charisma they hold in the original narratives. In this sense, modern martyrs' possessions also conserve the totem force described in the Durkheimian churinga, which are objects that condense the sense of belonging and of social identity, and that are revered as representations of the existence of the group, taking on a sacred quality in the eyes of the members of society who have created them. The relic of the virtual museum appears to irradiate this energy by taking the visitor from one sacralized object to another through the history of the martyr and physical contact with him, especially at the moment of his death.

In this sense, both virtual experiences emphasize the presence of the objects shown as part of the "passage of suffering" to which the martyrs were submitted.

The role of the relic in virtual tours (Figure 5) ${ }^{14}$ represents an interesting paradox; if the virtual experience ascribes to delocalization and makes the experience easier for the user with a screen, the object preserved-particularly clothing-implies an infusion of charisma by contact—in other words,

13 The above photograph shows the virtual tour of the Father Pro Museum at the spot where the clothes he was wearing when shot can be seen. As can be noted, they are preserved in a glass capsule behind a handrail (lower left) that does not allow visitors through.

14 The above photograph shows a close-up of the shirt Ignacio Martín Baró was wearing at the time of his death. It is part of the virtual tour by the IAPA mentioned above. 
belief, whether diffuse or explicit, that certain objects can transmit through direct contact with the martyred body. On this point, we must remember that primary relics are exclusively the mortal remains of the saints (Bynum 2011, p. 131), while so-called secondary relics are those that at some point were in direct contact with the body.

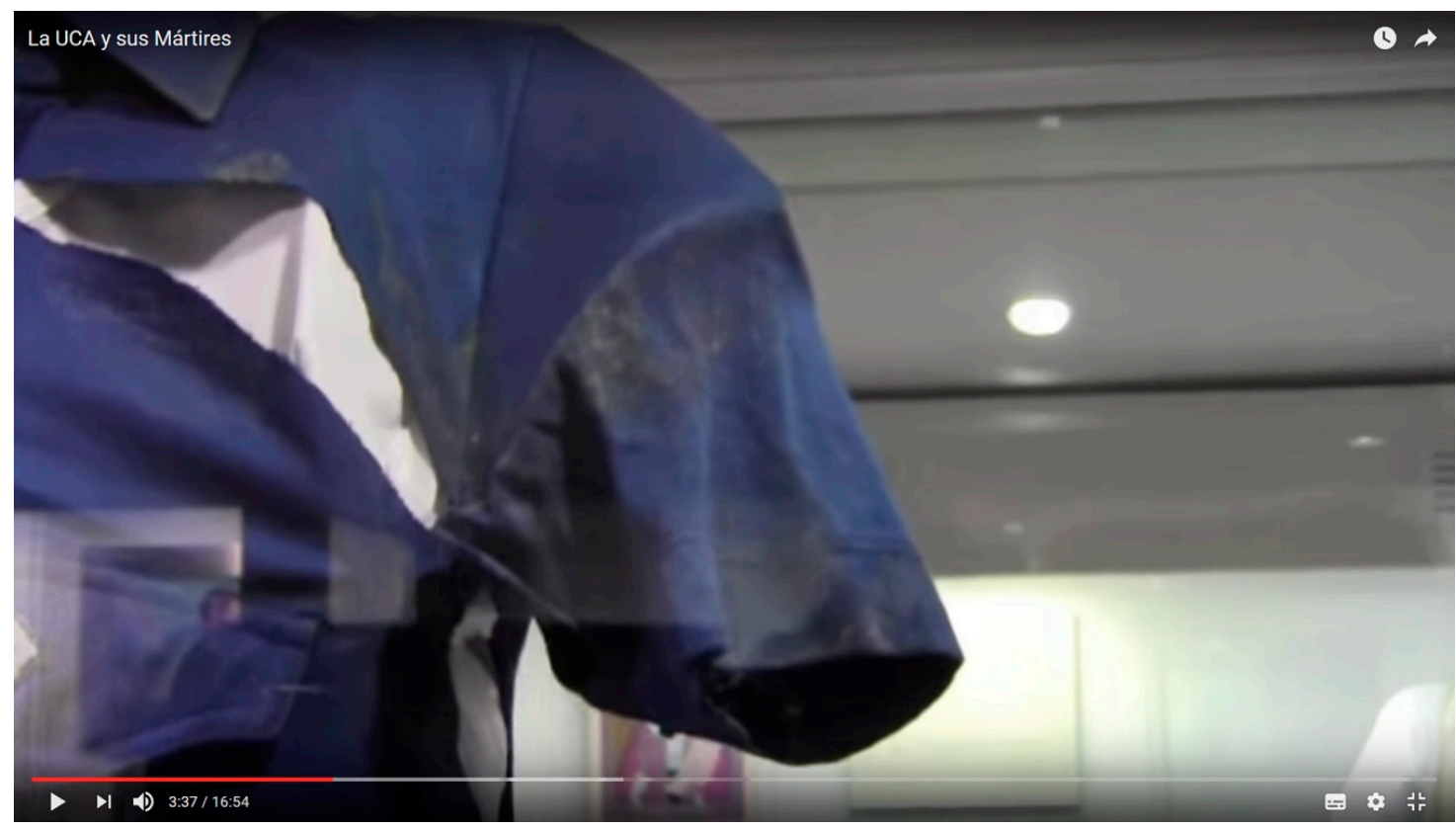

Figure 5. Ripped shirt belonging to Ignacio Martin Baró at display in the UCA museum. Screenshoot from Ochoa (2011).

Modern relics are extremely interesting artifacts, because they preserve both the memory of the martyr and his suffering, and that is why they are linked inextricably to the cause for which these people died. The Internet user looks unfailingly at the marks left on the martyr's body, and the experience of looking while alone can increase the empathy that cannot be found entirely in a museum (which is noisy and at least partially removed from the martyrial narrative). Thus, a virtual tour brings the Internet user closer to the martyr's experience. He or she can return again and again to particularly disturbing artifacts-those that show bodily violence most explicitly. Users do not have to worry about composure-restraint—of which the museum is an architect and a teaching tool.

Virtual tours and to some degree martyr museums themselves promote not only memory but also cult. They are located along the blurred lines between the secular and the religious, and instill a mystical sense in secular history-the virtual experience isolates the Internet user and allows him to connect emotionally more intensely with the artefacts chosen as vehicles of violence.

\section{Conclusions}

The so-called virtual museum is above all a tour that simulates a visit to the physical museum and makes it accessible to people who for whatever reason are unable to see it in person. It also transforms the museum experience in that the Internet user is not forced to follow the behavior guidelines that emerged with the museum as a modern mnemonic artifact.

The virtual projects analyzed in this article have in common that they make up part of the martyr narratives developed with the backing of Society of Jesus projects. Yet the abysmal differences in the contexts in which the UCA martyrs and Father Pro were killed explain the importance that in the former case is given to the collective nature of victimization.

The notion of collective victimhood related to theology after the Medellín Conference has been rescued in the virtual narratives about the UCA Martyr Memorial Hall, which is in line with 
the approaches taken by members of the Society of Jesus, including in particular a reflection by Sobrino (2012a, 2012b). On the other hand, the image given by the Father Pro virtual tour and web page is a different type, where the figure of the martyr stands out for his priestly investiture and his willingness to become a martyr for his faith in the most traditional sense of the word.

The two virtual tours are alike in the use they make of secondary relics as artifacts of memory that put the Internet user in contact with the notion of the debased body, the manner par excellence of showing violence that has been linked since its origins to the Christian tradition in general, and more specifically, to Catholicism.

Following Robert Geraci's work (Geraci 2014, p. 201), comparing these two online experiences allows seeing the social constellation of religion in which artifacts, meaning, space, and human intentions are transfixed and held together at the same time in the virtual environment.

Funding: This research received no external funding.

Conflicts of Interest: The author declares no conflict of interest.

\section{References}

\section{Primary}

El Salvador-Ministerio de Turismo. Available online: www.mitur.gob.sv/en/travel/centro-monsenor (accessed on 24 July 2019).

Ignacio, Ellacuría. Public Figure. Available online: https://www.facebook.com/Ignacio-Ellacuria-46745137275/ (accessed on 4 April 2019).

Padre Pro S.J. Public Figure. Official Cause for Canonization Facebook Page. Available online: https://www. facebook.com/search/top/?q=padre\%20pro\%20s.j (accessed on 17 March 2017).

Reliquias del beato Miguel Agustin Pro S.J. Available online: https://www.youtube.com/watch?v=nrfA9xNeFZ0 (accessed on 7 July 2019).

\section{Secondary}

Aspiring to know God. 2016. "While everybody is in Krakow". Available online: https://theaspiringcatholic. wordpress.com/2016/07/27/while-everyone-is-in-krakow/ (accessed on 8 August 2019).

Anderson, Benedict. 1991. Imagined Communities. London: Verso.

Anderson, Jon Lee. 2018. Archbishop Oscar Romero Becomes a Saint, but His Death Still Haunts El Salvador. The New Yorker. October 22. Available online: https://www.newyorker.com/news/daily-comment/archbishoposcar-romero-becomes-a-saint-but-his-death-still-haunts-el-salvador (accessed on 24 October 2018).

Bennett, Tony. 1995. The Birth of the Museum: History, Theory, Politics. New York: Routledge.

Brown, Peter. 1981. The Cult of the Saints. Chicago: University of Chicago Press.

Bynum, Caroline Walker. 2011. Christian Materiality. An Essay on Religion in Late medieval Europe. New York: Zone Books.

Castro, Oscar Arturo, and Víctor Flores García. 2013. El puño y el verbo. El legado jesuita de Centroamérica al mundo. México: Ibero Puebla.

Coddy, Sue Ann. 1997. Historical Museums on the World Wide Web. An exploration and critical analysis. In Public Historian. Berkeley: University of California Press, vol. 19, pp. 19-53.

Conferencia de Provinciales Jesuitas en América Latina CPJAL. 2018. Available online: http://www.cpalsj.org/ museo-en-honor-al-beato-miguel-agustin-pro-sj/ (accessed on 23 May 2018).

Deloche, Bernard. 2002. El Museo Virtual. Hacia una Ética de las Nuevas Imágenes. Gijón: Ediciones Trea, S.L.

Geary, Patrick J. 1990. Furta Sacra: Thefts of Relics in the Central Middle Ages. Princeton: Princeton University Press.

Geraci, Robert. 2014. Virtually Sacred: Myth and Meaning in World of Warcraft and Second Life. New York: Oxford University Press.

Hoornaert, Eduardo. 1988. The Memory of the Christian People. Maryknoll: Orbis Books.

Jones-Garmil, Katherine, ed. 1997. The Wired Museum. Emerging Technology and Changing Paradigms. Washington: American Association of Museums. 
Lopez Menendez, Marisol. 2015. La humanidad de los mártires. Notas para el estudio sociohistórico del martirio. Intersticios Sociales 10: 1-23.

Lopez Menendez, Marisol. 2016. Miguel Pro. Martyrdom, Politics and Society in Twentieth-Century Mexico. Lanham: Rowman \& Littlefield.

Meyer, Jean. 1974. La Cristiada, vol. 2. El Conflicto Entre la Iglesia y el Estado (1926-1929). México: Siglo XXI Editores. Museo de Miguel Agustín Pro SJ. 2015. Virtual Tour. Available online: http://www.padrepro.com.mx/recorridos/ museopadrepro.html (accessed on 24 May 2018).

Nora, Pierre. 2001. Les Lieux de Mémoire. Paris: Gallimard.

Ochoa, Jorge. 2011. Museo de los Mártires de la UCA. Available online: https://www.youtube.com/watch?v= Plo1f7mZJoA (accessed on 13 March 2017).

Organización de las Naciones Unidas. 1993. Comisión de la Verdad para El Salvador. In De la locura a la esperanza. La guerra de Doce años en El Salvador. Informe de la Comisión de la Verdad para El Salvador. New York: Naciones Unidas. First published 1992.

Rothkrug, Lionel. 2006. Death, Trust, \& Society: Mapping Religion \& Culture. Berkeley: North Atlantic Books.

Sobrino, Jon. 2012a. El Principio Misericordia. Bajar de la Cruz a los Pueblos Crucificados. San Salvado: UCA Editores.

Sobrino, Jon. 2012b. "Los mártires de la UCA. Exigencia y gracia”. In Revista Latinoamericana de Teología. Available online: http://www.redicces.org.sv/jspui/bitstream/10972/1542/1/RLT-2009-078-B.pdf (accessed on 17 March 2017).

Sociedad Interamericana de Prensa. V Congreso Regional. 2014. “La UCA y sus Mártires”. Available online: https://www.youtube.com/watch?v=J7ypd4Fkui0 (accessed on 13 March 2017).

Walsh, Kevin. 1992. The Representation of the Past. Museums and Heritage in the Post-Modern World. London: Routledge.

(C) 2019 by the author. Licensee MDPI, Basel, Switzerland. This article is an open access article distributed under the terms and conditions of the Creative Commons Attribution (CC BY) license (http://creativecommons.org/licenses/by/4.0/). 